\title{
Socio-economic Characteristics of Small Scale Buffalo Farms in Tanamalwila Area in Moneragala District of Sri Lanka
}

\author{
Premathilaka $\mathrm{S}^{1}$, Seresinhe $\mathrm{T}^{2}$, Gajaweera $\mathrm{C}^{2}$ \\ ${ }^{1}$ Veterinary Surgeon, Government Veterinary Office, Thanamalwila, Sri Lanka \\ ${ }^{2}$ Department of Animal Science, Faculty of Agriculture, University of Ruhuna \\ Mapalana, Kamburupitiya 81100, Sri Lanka \\ thakshas@ansci.ruh.ac.lk; profthakshala@yahoo.com
}

\begin{abstract}
A household survey was conducted, interviewing 100 buffalo farmers in fourteen Grama Niladhari divisions (GN) in Thanamalwila area to identify the present status of buffalo farming to improve the socio-economic status as well as to improve the livelihoods. Results reveal that direct involvement of males $(100 \%)$ was the prominent feature in this farming system while involvement of females was negligible. Among respondents, $80 \%$ farmers were between 21-50 ages while $30 \%$ were between 21-30 ages. Three types of breeds (Indigenous, Murrah and Nili-Ravi) and there crosses were existed. Major system of management was extensive $(90.71 \%)$ followed by semiintensive $(7.41 \%)$ and intensive $(1.85 \%)$. Herd size ranged between $12-251$ heads. Mostly natural breeding was practiced. Calving interval ranged from 12-30 months. Age at first calving was more than 42 months was $82 \%$ of buffalo herds. It was found that $24.22 \% \pm 4.8$ of total herd consisted of male with an atypical herd composition with $4.481 \pm 4.192$ excess bulls than the requirement. Income was mainly generated through selling of raw milk and lives buffaloes. It can be concluded that there is a chance to convert buffalo farming as economic venture in Thanamalwila area. Active participation of females, and younger generation should be ensured. As well as provision of technical knowledge is vital to make the industry is a profitable venture.
\end{abstract}

Key Words: Socio-Economic, Buffalo, Small Scale, Sri Lanka

\section{INTRODUCTION}

Although buffaloes have been neglected and under-utilized, they have been recognized to contribute significantly to the sustainability of mixed crop-livestock farming systems as well as to farmer's income and food security in Sri Lanka (Chantalakhana 2001). Small holder buffalo farming is a livelihood activity in many rural areas in Sri lanka due its multipurpose use. Buffalo 'curd' is a traditional unique product which is very popular all over country. Buffalo as a draft animal is well recognized in farming systems.

Uva Province can be recognized as one of the largest milk producer province in Sri Lanka. There were two administrative districts in Uva Province, namely Badulla and Moneragala. According to statistics of the DAPH (2012), Moneragala District has highest buffalo population in Uva Province, so Moneragala district was selected for the study. Out of 11 veterinary divisions in Moneragala District, Thanamalwila veterinary division was selected for the study due to availability of highest large ruminant population in Moneragala District (DAPH 2013). Thanamalvila is a predominantly buffalo area in Monaragala District where the second highest buffalo population $(46,390)$ reported (Livestock Statistics 2011).

Therefore, this study was conducted to identify the present status of buffalo farming to improve the socio-economic status as well as to improve the livelihoods in the area. 


\section{MATERIAL AND METHODS}

Prior to the structured survey, a rapid rural appraisal (RRA) was conducted through oral discussion with stakeholders of buffalo farming systems in the area. Discussion were held with the officers of the buffalo farming enterprises, officers of the formal milk collection network, small scale milk collectors, livestock development instructors, insemination technicians, etc.

The study was conducted using a pre-tested questionnaire. Hundred randomly buffalo farmers selected from fourteen Grama Niladhari (GN) divisions were interviewed. Farmers were selected to field survey based on population distribution in each GN division in Thanamalwila veterinary division.

Rearing buffaloes as primary or secondary source of income was the selected criteria for buffalo farmers. The questionnaire was designed to collect information on buffalo management aspects, inputs, output, socio economic situations, and involvement of household in buffalo farming.

\section{RESULTS AND DISCUSSION}

\section{Gender and age contribution to the dairy production}

The results of this study reveal that direct involvement of males $(100 \%)$ was the prominent feature in this farming system. Involvement of females was negligible while, they considered buffalo farming as a difficult task due to several reasons. Relatively, large herd size (Figure 1) and difficulties encountered in herding and feeding of buffaloes in forest areas were the main factors for the deviation of females. Demographic profile, level of education, occupation, age distribution, knowledge of buffalo farming and level of wealth determined the social structure of farming systems (Vithanage et al. 2013). Females also believed that buffaloes are aggressive animals with an unpredictable temperament. However, Abeygunawardena \& Abeygunawardena (1998) reported that if the buffaloes can be handled gently they can become docile as cattle and even females can deal with them. Further our finding showed that when the farm has less number of buffaloes, farmers are willing to practice cut and fed systems $(r=-0.301, p=0.027)$. Therefore, it could be suggested that buffaloes could be handled as docile animals especially in small farms to improve female participation.

The age of the buffalo farmers ranged from 17-65 years old, among respondents, $80 \%$ farmers were between 21-50 ages while 30\% were between 21-30 ages.

It was also seen that the involvement of farmers who are more than 51 years old $(16 \%)$ were less due to active participation needed in energetic activities such as herding in forest dwellings and bring back the herds in the night paddocking etc. Further farmers had involved full time with animals during the dry periods, especially in feeding to maintain satisfactory productions levels could also being a reason for the deviation.

One important feature was that the increasing involvement of younger $(<30$ years of age) generation (34\%) in buffalo farming. This shows the importance to convert buffalo farming as economic venture, with more technical knowledge how to make the industry a sustainable livestock enterprise in the area. If younger generation involves in the industry its sign of future sustainability and their actions will be reinforced by the relatively higher income generation (Vithanage et al. 2013). Majority (98.1\%) of the farmers in the area stated that purpose of buffalo rearing is to both producing milk as well as meat. 


\section{Management systems}

The results revealed that major system of management in the area was extensive $(90.71 \%)$ followed by semi-intensive $(7.41 \%)$ and intensive $(1.85 \%)$. Zero supplementary feeding, absence of housing and free grazing was considered as characteristics of this management system. Abeygunawardena \& Abeygunawardena (1998) also mentioned that free-grazing extensive management system and semi-intensive management system as most widespread management systems in Sri Lanka in relation to buffaloes.

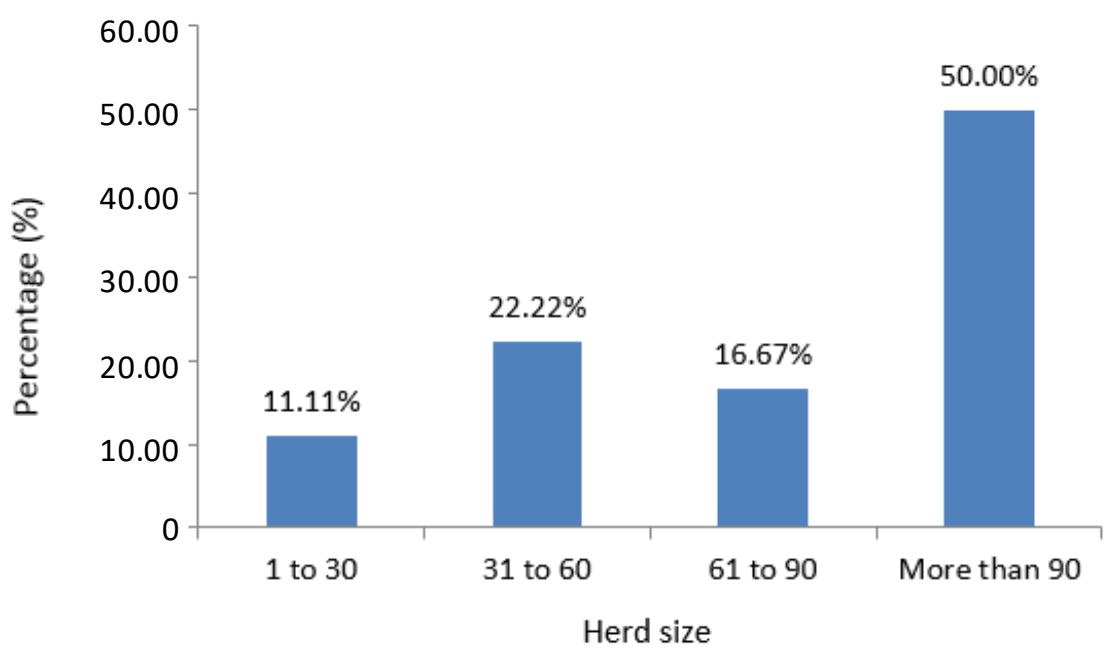

Figure 1. The size and composition of buffalo herds

Herd size ranged between 12-251 heads. However, the majority of respondents (50\%) were having more than 90 heads. Results showed that farmers tend to rear relatively large buffalo herds. Under the extensive management system, it was the low cost production system. Furthermore, Abeygunawardena \& Abeygunawardena (1998) also stated that buffalo herd ranged from 1-242 while the averages herd size was 22.5 heads in Sri Lanka.

\section{Breed combination within a herd}

There were three types (Indigenous, Murrah, Nili-Ravi) of buffalo breeds and their crosses existed in the area. According to the finding of the study, majority of farmers (75.93\%) reared local buffalo with Murrah or Nil -Ravi cross bred. 98.15\% of respondents preferred to rear at least one exotic buffalo breed along with local buffalo. By replacing the local buffalo in the herd with exotic crossbred, farmers wishes to increase the milk production from the herd. Moreover, government veterinary office in Thanamalwila promotes exotic buffalo breeds by giving $50 \%$ of subsidy policy.

\section{Type of breeding}

This is not surprising considering the difficulties that are encountered in the heat detection under the present systems of management. Most of farms depended on natural breeding. Introduction of exotic semen for buffalo AI was not much popular in the area, however only two farmers $(3.70 \%)$ were practicing artificial insemination (AI) for their buffalo herds. Numerous workers (Barile 2012; Noguera et al. 2013) found that the use of AI as a method of breeding buffaloes was negligible. This may be due to poor estrus expression of female buffaloes and also because of misbelieves of the farmers on AI, etc. 
Most of buffaloes were crossed with wild buffaloes due to rearing them close to Udawalawa and Lunugamvehera National Parks However majority of farms reared cross bred buffalos thus they have better genetic potential to develop this industry.

\section{Age at firts calving}

Figure 2 shows that age at first calving was between 30-36 months in 2\% of buffalo herds in the study group and it was 36-42 months in $14 \%$ of buffalo herds. However, age at first calving was more than 42 months in $82 \%$ of buffalo herds in the study group. The reported age at first calving in buffalos varied from 36-48 months (Fadzil 1969, Shah et al. 1987). So, it could be stated that the age of first calving in Thanamalwila veterinary range was comparable to the findings of Fadzil (1969). Hence, age at the first calving has to be reduced to make it as a profitable industry.

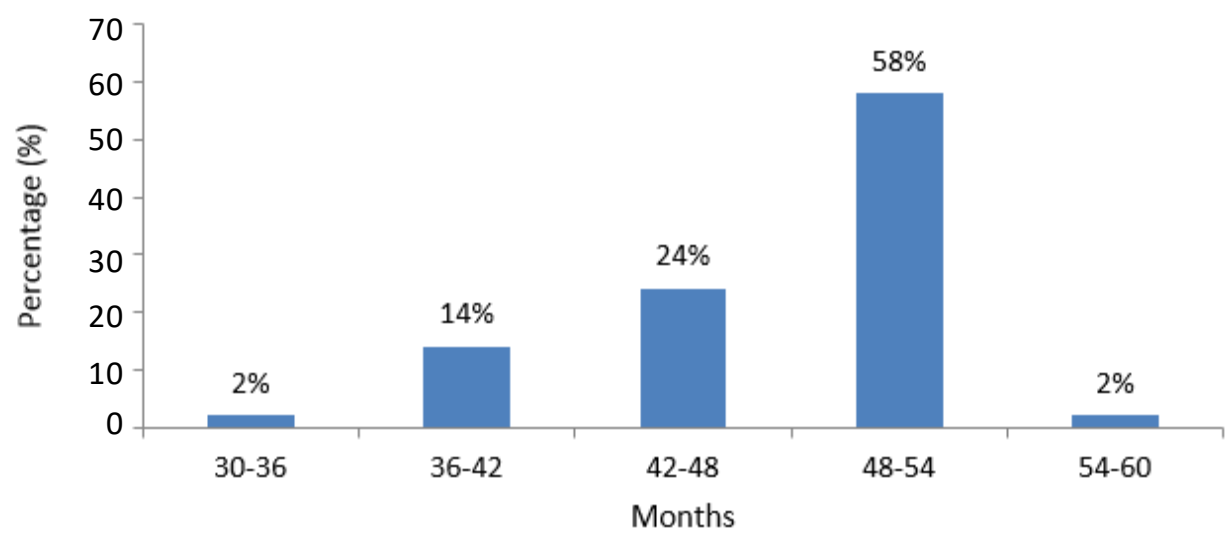

Figure 2. Age of first calving in study area

\section{Calving interval}

Calving interval was 12-18 months in $18 \%$ of buffalo herds and calving interval was 18-24 months in $80 \%$ of buffalo herds and it was $24-30$ months in $2 \%$ of herds. Parera (2011) found that average calving interval of indigenous buffaloes in Sri Lanka was $384.9 \pm 62.9$ days and the calving interval was ranged from 329 to 816 days. The findings of present study were almost similar.

Further, the findings of the present study also were similar to the findings of EISheikh \& Mohammed (1967) who found that first calving interval of Egyptian buffalo was 484.74 \pm 2.86 days. Fadzil (1969) carried out an experiment on Swamp buffalo in Malaysia under village condition and found that calving interval was 639 days.

\section{Sex and age distribution within total herds}

From birth to six month of age, male to female ratio was closely 1:1 but it has drastically changed up to 1:4 after two years. In general calves were not sold for meat at market, therefore it was obvious that farmers have neglected especial care of male calves. It was clearly shown that $24.22 \% \pm 4.8$ of total herd consisted of male calves. According to the Sri Lankan regulation, it has banned to slaughter the buffalos. Therefore it has adversely affected to increase the male (unproductive) population and thus caused drag down the farm profit. Usually one bull is enough to breed 15 cows naturally. However, all herds maintained atypical herd composition with $4.481 \pm 4.192$ excess bulls than the 
requirement. Though there is strict regulation against buffalo slaughtering and no organized market available for buffalo meat, however all the farmers in the area stated that purpose of buffalo rearing was both to produce milk as well as meat.

Table 1. Sex and age distribution with in total herds of 0-2 years old

\begin{tabular}{lccc}
\hline \hline Age (months) & Male $(\%)$ & Female $(\%)$ & Total $(\%)$ \\
\hline $0-6$ & 6.29 & 7.24 & 13.53 \\
$6-12$ & 4.69 & 5.01 & 9.70 \\
$12-24$ & 7.17 & 8.17 & 15.34 \\
$24-48$ & 7.45 & 10.98 (heifers) & 18.43 \\
$>48$ & 0 & 42.99 (cows) & 42.99 \\
\hline
\end{tabular}

\section{Economic status}

Even though, milk price totally depends on the fat content, buffalo milk collector in Thanamalwila veterinary range collected milk from farmers using only lactometer reading. The average farm gate price for one liters of milk is around seventy five rupees.

Most of the farmers in Thanamalwila veterinary range did not involve in producing milk -products such as curd. $92 \%$ farmers are used to earn money by only selling of raw milk. However, approximately $8 \%$ farmers produced curd. Price of one liter curd pot varied from LKR 130-160. Curd fetched a better price than liquid milk although manufacture of curd involved additional work.

According to the finding of the study, $74 \%$ respondents sold at least one head buffalo during past 12 months from the time period which conducted the study. It revealed that live animal selling also as a source of income in buffalo farmers in Thanamalwila veterinary region. Farmers sold bulls (when they are 2-3 years of age) as they are nonproductive animals in the herd. Some of them were sold as breeding animal to other farms and some of them were sold to black market, mainly for beef production. According to Abeygunawardena \& Abeygunawardena (1998) buffalo rearing used as a way of capital farming and in the event of cash urgent farmers are tend to sell one or two heads to overcome the financial issues. Same study revealed the use of buffaloes as a part of dowry system.

\section{CONCLUSION}

Buffalo farming in Thanamalvila area is in a primitive stage. Therefore it needs to reconsider supports and attention to develop buffalo industry for food security and sustainable rural development. Buffalo's owners do not rear their buffaloes in a scientific way rather than following traditional methods. A typical herd composition observed due to restriction of slaughter policy, thus increasing male (unproductive) population in herds cause drag down of farm profit. There are possibilities to convert buffalo farming as economic venture in Thanamalwila area. However, active participation of females, and younger generation should be ensured. Provision of technical knowledge is a vital aspect and farmers should be educated to make processed products rather than selling of raw milk to generate significantly higher income. 


\section{REFERENCES}

Abeygunawardena H, Abeygunawardena IS. 1998. Water buffalo farming in Sri Lanka: Production systems, uses, potentials and constraints. In: Subasinghe DHA, Horadagoda NU, Abeygunawardena $\mathrm{H}$, Siriwardena JA, editors. Water buffalo-improved utilization through new technologies. Colombo (Sri Lanka): National Science Foundation. p. 11-22

Barile VL. 2012. Technologies related with the artificial insemination in buffalo. J Buffalo Sci. 1:139-146.

Chantalakhana C. 2001. Urgent need in buffalo development for food security and self-sufficiency. In: National Workshop on Swamp Buffalo Development, Hanoi, Vietnam. 2001 [internet]. Available from: http://www.mekarn.org/procbuf/chan.htm, accessed on 04/11/2012.

DAPH. 2012. Annual report-2012. Peradeniya (Sri Lanka): Department of Animal Production and Health Sri Lanka.

DAPH. 2012. Annual report-2013. Peradeniya (Sri Lanka): Department of Animal Production and Health Sri Lanka.

El-Sheikh AS, Mohammed AA. 1967. The reproductive performance of the egyptianbuffalo. J Anim Prod. 5:99-117

Fadzil M. 1969. A study on the calving frequency and age at the time of calving. Malaysian livestock statistics. 2011. Polduwa Rd (Sri Lanka): Department of Census and Statistics.

Noguera SEG, Vale WG, Ribeiro HFL, Rolim FST, Reis AN, Sousa JS, Silva AOA. 2013. Fixedtime artificial insemination in cows and buffaloes using an intravaginal releasing progesterone insert swamp buffaloes. Malays Agric J. 47:203-206.

Parera BMAO. 2011. Reproductive cycles of buffalo. Anim Reprod Sci. 124:194-199.

Shah SKR, Mir FA, Usmani RHI. 1987. The performance of rural nili-ravi buffaloes (Bubalus bubalis) v. Gestation length. Indian J Ani Prod.4:88-90.

Vithanage UYN, Mahipala MBP, Gunartne IHP, Cyril HW. 2013. A comparison of animal-crop mixed farming systems in dry lowland Sri Lanka. 25:2013. 